\title{
GROWTH AND SYMPTOMS OF DEFICIENCY OF MICRONUTRIENTS IN YOUNG PLANTS OF JUTE
}

\author{
CRESCIMENTO E SINTOMAS DE DEFICIENNCIA DE MICRONUTRIENTES EM \\ PLANTAS JOVENS DE JUTA
}

\author{
Ismael de Jesus Matos VIÉGAS ${ }^{1}$; Jessivaldo Rodrigues GALVÃ ${ }^{2}$; \\ Cassio Rafael Costa dos SANTOS $^{3}$; Gilson Sérgio Bastos de MATOS ${ }^{1}$; \\ Diocléa Almeida Seabra SILVA ${ }^{1}$; Rosemiro dos Santos GALATE ${ }^{1}$; Felipe Oliveira Ribeiro ${ }^{4}$ \\ 1. Professor, Federal Rural University of Amazon; 2. Agronomist, Federal Rural University of Amazon; 3. Forestry Engineer, Federal \\ Rural University of Amazon; 4Agronomist, Belém-PA
}

\begin{abstract}
The knowledge of micronutrients for Jute (Corchorus capsularis L.) plants might be a valuable tool to the subsidize taking of decisions to the management of such species. The objective of this study was to describe the symptoms of micronutrient deficiencies in jute plants and to analyze micronutrient contents in leaves, stems, and roots. The experiment was carried out in a greenhouse, with six treatments and four replications in a randomized block design. The treatments were, as follows: Complete solution $(\mathrm{C})$ and solution with the omission of the following nutrients: $\mathrm{B}$, $\mathrm{Cu}$, $\mathrm{Fe}, \mathrm{Mn}$, and $\mathrm{Zn}$. Except for $\mathrm{Cu}$ deficiency, the morphological alterations were easily characterized for all nutrients evaluated, in which $\mathrm{Fe}$ and $\mathrm{Zn}$ were the first and the last to cause symptoms in plants, respectively. In general, the nutrients that were most limiting to the growth of Jute plant and for dry mass were Fe and B. The omission of B, Mn and Fe limited root growth while the $\mathrm{Zn}$ and $\mathrm{Cu}$ deficiencies limited the growth of the aerial part. The nutrient contents were ordered as it follows: $\mathrm{Fe}>\mathrm{Mn}>\mathrm{Zn}>\mathrm{B}>\mathrm{Cu}$ in the leaves, $\mathrm{Fe}>\mathrm{Mn}>\mathrm{B}>\mathrm{Zn}>\mathrm{Cu}$ in the stem and $\mathrm{Fe}>\mathrm{Zn}>\mathrm{Mn}>\mathrm{B}>\mathrm{Cu}$ in the roots. $\mathrm{For}$ seedings of Jute, the deficiency of $\mathrm{Fe}$ and $\mathrm{B}$ are the most limiting and the suitable nutritional contents for those seedlings are $11.37 ; 8.99 ; 346.14 ; 248.88$ and 77,28 mg.kg ${ }^{-1}$ for $\mathrm{B}, \mathrm{Cu}, \mathrm{Fe}, \mathrm{Mn}$ and $\mathrm{Zn}$ in the leaves, respectively.
\end{abstract} development.

KEYWORDS: Corchorus capsularis L. Mineral nutrition. Micronutrients requirement. Nutrient solution. Plant

\section{INTRODUCTION}

Jute (Corchorus capsularis L.) is a plant used in the textile production. It is a species that belongs to the botanical Family Tiliaceae (SILVA; MOTA 1991). Jute was introduced in Brazil to reduce the import of fibers caused by the deficit of its production (HIROCE et al. 1987). Studies developed in the Amazon with interest in jute are primarily concerned with genetic improvement of regional varieties and some plant breeding practices.

Concerning to jute nutritional aspects, few studies were carried out, especially on micronutrients. The mineral nutrients which are found in small concentrations in the plant tissues are considered micronutrients (BARBOSA et al. 2009). Choudhary et al. (2013) state that little is known about the nutritional status and assessing regarding cultivated Jute plants, which represents a limitation on its yield development.

As a result, the diagnosis due to the lack of micronutrients may be considered an efficient technique to monitor the response of species regarding nutritional requirements of such elements (MIRANDA et al. 2010). This can be a valuable tool to establish some decision taking.
Consequently, the concern about the management and reposition of micronutrients must be a target of great interest in crop research, to reach excellent levels of nutritional efficiency (ALMEIDA et al. 2014). Wei et al. (2006) found that the deficiency of micronutrients is recurrent in many species since such nutrients are very sensitive to environmental variation.

The present study was performed under the following hypothesis: Among $\mathrm{B}, \mathrm{Fe}, \mathrm{Cu}, \mathrm{Mn}$ and $\mathrm{Zn}, \mathrm{B}$ and $\mathrm{Fe}$ are the most limiting nutrients for Jute young plants. Hence, the objective of this study was to evaluate the nutritional status and the deficiency symptoms of jute seedlings (Corchorus capsularis L.) as a function of some micronutrients omission.

\section{MATERIAL AND METHODS}

The experiment was carried out in a greenhouse in Eastern Amazon, Belém, State of Pará. The area presents a megathermal and humid climate, classified according to the Köppen's climate system. The average temperature is $26.4^{\circ} \mathrm{C}$, with a relative air humidity of $84 \%$ and annual precipitation of 3,001.3 mm (WATRIN; HOMMA, 2011). 
The experimental design was in randomized blocks, with six treatments and four. The following treatments were established: complete solution (treatment 1) (C), taken as control and omission of boron $(-\mathrm{B})$, copper $(-\mathrm{Cu})$, iron $(-\mathrm{Fe})$, manganese ($\mathrm{Mn})$ and zinc (-Zn) (treatments 2, 3, 4, 5 and 6, respectively).

For jute cultivation in nutrient solution, seeds of Lisa variety were used. They are provenient from experimental fields of Embrapa Eastern Amazon, in Alenquer, State of Pará. The seeds were put for sowing for seedlings production, which were reallocated to pots containing nutrient solution with formulation proposed by Bolle-Jones (1954).

Plastic pots with volumetric capacity of $5 \mathrm{~L}$ were used with silica (type zero coarse). Plants were acclimatized for a period of 35 days in nutrient solution with different dilutions which were sequenced $(0,20$ and $50 \%$ of solution concentration). After plants had reached an average height of $30 \mathrm{~cm}$, they were submitted to treatments (complete solution and solution with micronutrients omission) until the manifestation of nutritional deficiency symptoms.

The nutrient solutions were provided to the pots by percolation and they were renewed in a gap of 15 days. The solutions of the treatments were provided in the morning period and drained in the afternoon period, daily, with a duration of 8 hours. Levels of the of the solution in the collector flasks were checked daily. The volume was completed to 1 litter with distilled water.

When all deficiency symptoms regarding to micronutrients omissions showed themselves well defined, the plants of the experiment were measured and then collected and divided in leaves, stem and root. Then, those parts were dried in ovens with forced air circulation at $70^{\circ} \mathrm{C}$, for determination of dry weight.

The following quantitative variables were determined: Plant height $(\mathrm{PH})$ and stem diameter
(SD) in $\mathrm{cm}$; leaf dry mass (LDM), stem dry mass (SDM), root dry mass (RDM), dry mass of the aerial part (ShDM), total dry mass (TDM) and aerial part dry mass/root dry mass ratio (ShDM/TDM) in g.plant ${ }^{-1}$; relative growth in \%; and micronutrients content (B, Fe, $\mathrm{Mn}, \mathrm{Zn}$ and $\mathrm{Cu}$ ) in $\mathrm{mgkg}^{-1}$.

Such quantitative variables were submitted to analysis of variance $(\mathrm{p}<0.05)$ using the F-Test. When significant, the Tukey test was applied for comparison of the means $(\mathrm{p}<0.05)$. Those analyses were performed with the use of the statistical software SAS (SAS Institute, 2006). Moreover, the micronutrients contents of each treatment were submitted to a Pearson's Correlation Analysis with $5 \%$ of significance, in order to assess the influence that such nutrients exert to each other in the different plant tissues evaluated.

\section{RESULTS AND DISCUSSION}

\section{Visual Diagnosis}

Except for $\mathrm{Cu}$, all micronutrients showed symptoms of deficiency. At 75 days, after application of the treatments, the symptoms of B deficiency were manifested. The younger leaves were thinner than the plants of the control treatment. With the severity of symptoms, leaves became deformed. Such B omission also resulted in a decrease in plant height and an increase in some buddings.

Because B is transported via xylem (almost immobile in plant tissues), the symptoms of deficiency could be seen in the younger tissues and in the growth region of the plants (Figure 1). Similar visual symptoms of $B$ in jute plants were also found by Viégas et al. (1992). The B deficiency impairs the transport and the action of growth regulators, with an increase in the level of indoleacetic acid (AIA), which may inhibit the vegetative development.
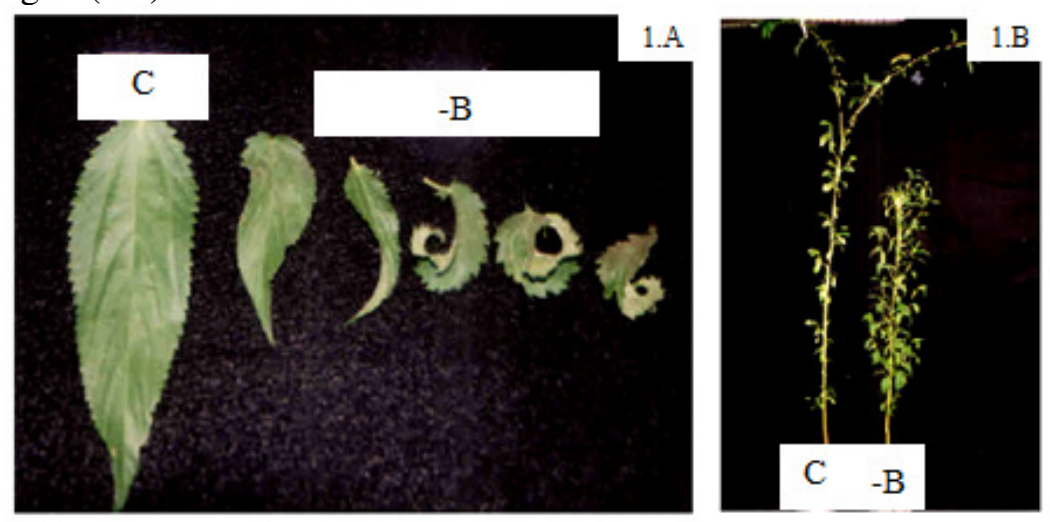

Figure 1. Leaves of jute with and without deficiency of B (1.A) and jute plants growth with and without deficiency of B (1.B). 
So, such deficiency disturbs the development of the plants due to the reduction of proteins synthesis, problems in the formation of the cell wall and the transport of photosynthesis products, promoting the accumulation of phenolic compounds (Façanha et al. 2008).

On the $13^{\text {th }}$ day after application of treatments, the deficiency caused by omission of $\mathrm{Fe}$ manifested. Among the micronutrients evaluated in this study, Fe was the first to appear, what denotes the high degree of sensibility of jute in relation to the lack of this nutrient. The symptom was verified in young leaves, which presented chlorosis and a green coloration in the veins of the leaves, forming a fine mesh on the yellow background (Figure 2.A). As symptoms intensified, leaves became completely chlorotic and then whitish (Figure 2.B). The omission of $\mathrm{Fe}$ also reduced plant height (Figure 2.C).

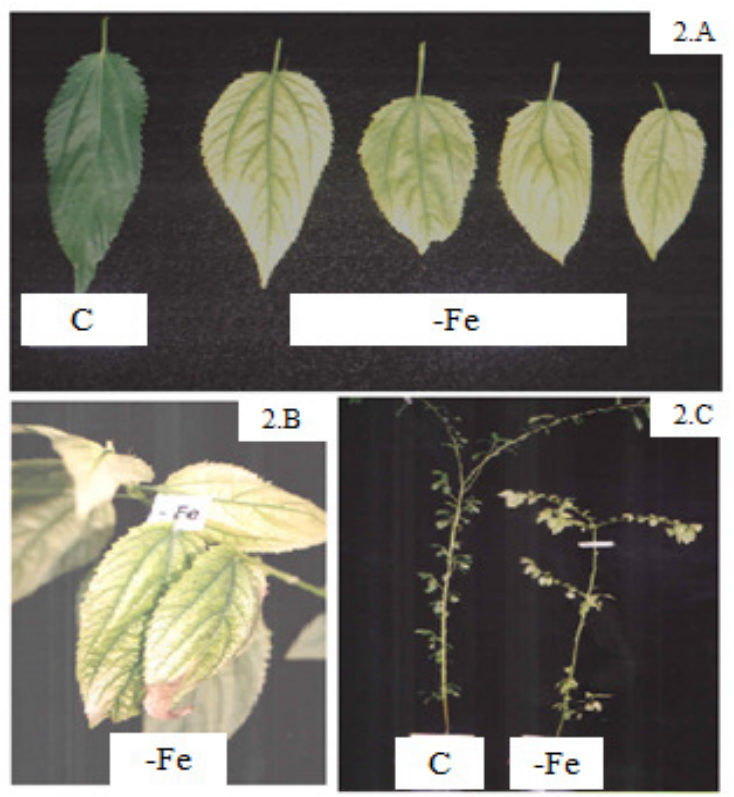

Figure 2. Leaves of jute with and without deficiency of $\mathrm{Fe}$ (2.A); Leaves of jute with chlorosis caused by the lack of $\mathrm{Fe}$ (2.B); and jute plants grown with and without deficiency of $\mathrm{Fe}$ (2.C).

The symptoms of the lack of Fe described were also similar to those found in a study by Fasabi (1996) using Malva sylvestris L. Among the consequences of $\mathrm{Fe}$ deficiency in plants, it is possible to highlight the decrease of chlorophyll formation and ferredoxin (essential protein in the transport of electrons in the photosynthesis process), justifying the presence of tissue chlorosis because of the predominance of yellowish pigments (xanthophyll and carotene) (MATOS et al. 2013).
Similarly, symptoms were described by Fasabi (1996) in Malva plants.

The plants with the omission of Mn showed the first symptoms of deficiency only after 63 days of application of the treatments. Symptoms manifested in younger leaves which showed chlorosis between the secondary nerves in a crosslinked form, with a coarse green mesh on the yellowish background (Figure 3.A).

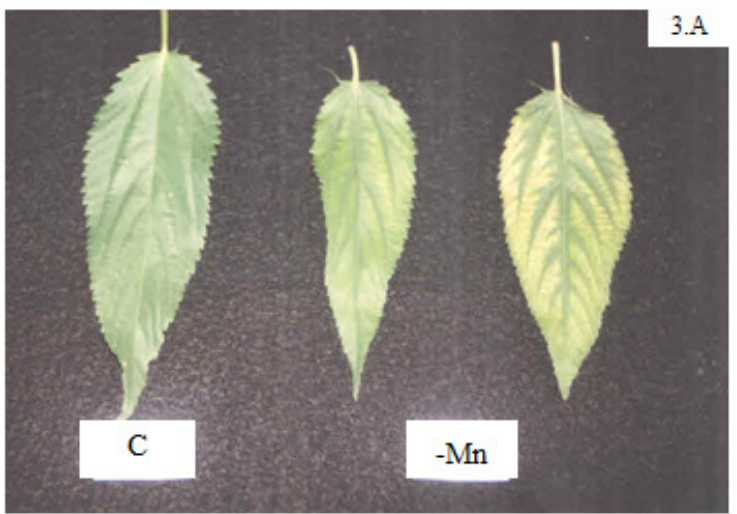

Figure 3. Leaves of jute with and without deficiency of Mn. 
In relation to $-\mathrm{Mn}$, the symptoms found in here are prevalent in fibrous species. It is known that $\mathrm{Mn}$ is present in the superoxide dismutase antioxidant enzyme and its smaller production leads to an oxidant stress, characterized by the coloration ranging from yellow to brown among the leaf ridge (Figure 3). This is a result of the accumulation of reactive species of oxygen, harmful to plant tissues, inside the chloroplasts (SCHMIDT et al. 2016). Moreover, the lack of $\mathrm{Mn}$ reduces the photosynthesis process because the nutrient is involved in the water photolysis (TAIZ; ZEIGER, 2010).

Zinc was the micronutrient with the latest symptom of deficiency to manifest, showing an internerval chlorosis in younger leaves, which is in agreement with the results found by Marschner (2012). No visual symptoms were found for deficiency of $\mathrm{Cu}$, which may be justified by the small requirement of jute plant to this micronutrient.

The internerval chlorosis in younger leaves observed in $-\mathrm{Zn}$ treatment is related to metabolic process and structures formation in plant tissues. Among the factors that lead to chlorosis in plant tissues according to $\mathrm{Zn}$ deficiency are related to the decrease in the reduction of nitrate as well as the decrement in the amount of chloroplasts (TAIZ; ZEIGER, 2010).

\section{Plant Biometrics}

It was found that means of all the treatments with omission of nutrients were lower than the complete treatment concerning TDM and mass of almost all parts of the plants. However, there are exceptions to the SD from - Fe that was lower than the SD from $\mathrm{C}$ and LDM from $-\mathrm{B}$, which was statistically similar to the LDM from C (Table 1).

Table 1. Plant height (PH), stem diameter (SD), leaf dry mass (LDM), stem dry mass (SDM), root dry mass (RDM), aerial part dry mass (ShDM), total dry mass (TDM) and ShDM/TDM ratio of jute plants grown in different solutions with omission of micronutrients.

\begin{tabular}{|c|c|c|c|c|c|c|c|c|}
\hline \multirow{2}{*}{ Treatment } & PH & SD & LDM & SDM & ShDM & RDM & TDM & ShDM/RDM \\
\hline & \multicolumn{2}{|c|}{-------cm------ } & \multicolumn{6}{|c|}{ 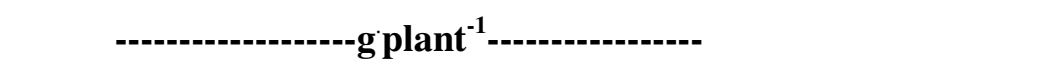 } \\
\hline $\mathbf{C}$ & $214.08 \mathrm{a}$ & $12.55 \mathrm{a}$ & $6.70 \mathrm{a}$ & $21.66 \mathrm{a}$ & $28.36 \mathrm{a}$ & $15.74 \mathrm{a}$ & $44.10 \mathrm{a}$ & $1.81 \mathrm{c}$ \\
\hline$-\mathrm{Fe}$ & $165.10 \mathrm{bc}$ & $10.06 \mathrm{~b}$ & $3.68 \mathrm{~d}$ & $9.94 \mathrm{c}$ & $13.62 \mathrm{c}$ & $6.04 \mathrm{c}$ & $19.67 \mathrm{e}$ & $2.24 \mathrm{bc}$ \\
\hline$-M n$ & $194.40 \mathrm{ab}$ & $12.36 \mathrm{a}$ & $5.17 \mathrm{~cd}$ & $17.46 \mathrm{~b}$ & $22.64 \mathrm{~b}$ & $9.15 \mathrm{~b}$ & $31.79 \mathrm{~d}$ & $2.48 \mathrm{~b}$ \\
\hline$-\mathbf{Z n}$ & $186.46 \mathrm{~b}$ & $12.00 \mathrm{a}$ & $6.09 \mathrm{ab}$ & $16.09 \mathrm{~b}$ & $22.19 \mathrm{~b}$ & $14.05 \mathrm{a}$ & $36.25 b c$ & $1.63 \mathrm{c}$ \\
\hline$-\mathbf{C u}$ & $200.50 \mathrm{ab}$ & $12.38 \mathrm{a}$ & $5.27 \mathrm{bc}$ & $17.05 \mathrm{~b}$ & $22.32 \mathrm{~b}$ & $13.40 \mathrm{a}$ & $35.72 \mathrm{c}$ & $1.71 \mathrm{c}$ \\
\hline$-B$ & $134.88 \mathrm{~d}$ & $12.10 \mathrm{a}$ & $6.37 \mathrm{a}$ & $16.03 \mathrm{~b}$ & $22.40 \mathrm{~b}$ & $8.06 \mathrm{bc}$ & $30.46 \mathrm{~d}$ & $2.79 \mathrm{a}$ \\
\hline M.D.S. & 21.59 & 0.84 & 0.91 & 3.01 & 3.14 & 2.38 & 3.82 & 0.44 \\
\hline CV\% & 6.93 & 4.17 & 9.64 & 10.79 & 8.39 & 12.62 & 12.30 & 6.78 \\
\hline
\end{tabular}

M.D.S.: minimal difference of significance; CV\%: coefficient of variation. Means followed by the same letter in the columns do not differ from each other by the test of Tukey at $5 \%$ of significance.

The smallest means of PH were observed when plants were submitted to treatment with omission of B (-B). Stem diameter, leaf dry matter, stem dry matter, aeriap part dry matter, and root dry matter presented the lowest values with $-\mathrm{Fe}$ treatment. The $-\mathrm{Fe},-\mathrm{Mn}$ and $-\mathrm{Cu}$ treatments were the treatments which affected LDM the most. Regarding to SDM, RDM and TDM, the treatments $-\mathrm{Fe}$ followed by $-\mathrm{B}$ were the most limiting when compared to $\mathrm{C}$ treatment. For ShDM, the most limiting treatment was $-\mathrm{Fe}$.

For $\mathrm{ShDM} / \mathrm{RDM}$, it is important to emphasize that the higher its value is the more limited will be the essential element for roots in comparison to the aerial part. Hence, the omission that constrained the root growth more than shoot growth were $-\mathrm{B}$ followed by $-\mathrm{Mn}$ and $-\mathrm{Fe}$. On the other hand, elements that were more limiting to aerial part than to root system were $-\mathrm{Zn}$ and $-\mathrm{Cu}$.

The relative growth of the aerial part were in accord to the following order for the treatments: $\mathrm{C}>-\mathrm{Cu}>-\mathrm{Zn}>-\mathrm{Mn}>-\mathrm{B}>-\mathrm{Fe}$. Among treatments with nutrients omission, it was found that jute was less affected by the lack of $\mathrm{Cu}$ with a reduction by $18.17 \%$ of TDM. On the other hand, -Fe was the treatment that most affected the jute dry mass production (55.27\%) (Figure 4).

ShDM, RDM, and TDM were significantly affected by $-\mathrm{B}$ treatment. In a study performed by Ramos et al. (2009), the omission of B influenced the growth of the plants significantly. Such reduction in growth is probably due to the low 
availability of these micronutrients in soils under natural conditions.

The deficiency of $\mathrm{B}$ constraints the root growth because, with this, a decrease in carbohydrates and lignin and auxin production occurs (FAÇANHA et al. 2008). In turn, the lack of Fe directly affects the reduction of cell enlargement of apical zones of the root system, as found by Moretti et al. (2012), while Mn deficiency influences the reduction of carbohydrates content because of the decrease in photosynthesis, strongly connected to rhizogenesis. For these authors, this is probably because of the dysfunction caused by the auxins metabolism, which reduces the leaf development.

For Cunha et al. (2009), the momentary deficiency of $\mathrm{Cu}$ in young plants, especially for its root system, might be propitious, because this nutrient absence often results in a little activity of AIA oxidase enzyme. This favors a lower auxin degradation and a lower availability of this enzyme to plant development, as found by these authors.
ShDM, RDM and TDM were meaningly affected by $-B$ treatment. It is known that B is responsible for the cells division and development, which has a direct impact in plants growth (BRADY; WEIL, 2013). Viégas et al. (2004) evaluated the effect of the omission of some nutrients on Myrciaria dubia (H. B. K. Mc Waugh) growth and they obtained a reduction of approximately $60 \%$ in the dry matter production of the leaves, approximately $70 \%$ in the dry matter production of the stem and $75 \%$ in the dry matter production of the root, when compared to control treatment. Such authors evidenced the limitation caused by $B$ in the vegetative growth of the plants.

\section{Micronutrients Content}

As expected, the lower contents of $\mathrm{B}, \mathrm{Cu}$, $\mathrm{Fe}, \mathrm{Mn}$ and $\mathrm{Zn}$ in leaves, stems and roots tissue were found in treatments with individual omission of such nutrients in the nutrient solution (Table 2). In $\mathrm{C}$ treatment, the increasing order of content of these micronutrients was: $\mathrm{Fe}>\mathrm{Mn}>\mathrm{Zn}>\mathrm{B}>\mathrm{Cu}$.

Table 2. Micronutrients content $\left(\mathrm{mg} \mathrm{kg}^{-1}\right)$ in leaves, stem and root of jute plants in different solutions with and without omission of micronutrients.

\begin{tabular}{|c|c|c|c|c|c|}
\hline \multirow{3}{*}{ Treatment } & B & $\mathbf{C u}$ & $\mathbf{F e}$ & Mn & \multirow[t]{3}{*}{$\mathbf{Z n}$} \\
\hline & \multicolumn{4}{|c|}{ 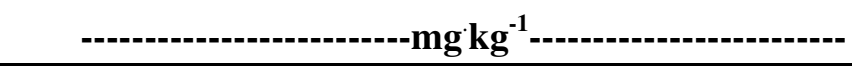 } & \\
\hline & \multicolumn{4}{|c|}{ Leaf } & \\
\hline $\mathbf{C}$ & $11.37 \mathrm{ab}$ & $8.99 \mathrm{c}$ & $346.14 \mathrm{~b}$ & $249.88 \mathrm{~b}$ & $77.28 \mathrm{c}$ \\
\hline$-\mathbf{B}$ & $6.591 \mathrm{~d}$ & $8.84 \mathrm{c}$ & $249.49 \mathrm{~d}$ & $225.12 \mathrm{~b}$ & $70.62 \mathrm{c}$ \\
\hline$-\mathbf{C u}$ & $10.54 \mathrm{~b}$ & $5.09 \mathrm{~d}$ & 432.78 a & $257.31 \mathrm{~b}$ & $92.59 \mathrm{~b}$ \\
\hline$-\mathrm{Fe}$ & $12.293 \mathrm{a}$ & $29.86 \mathrm{a}$ & $159.38 \mathrm{e}$ & $313.79 \mathrm{a}$ & $143.69 \mathrm{a}$ \\
\hline$-\mathbf{M n}$ & $10.50 \mathrm{~b}$ & $10.67 \mathrm{~b}$ & $386.33 \mathrm{ab}$ & $28.33 \mathrm{c}$ & $81.77 \mathrm{c}$ \\
\hline$-\mathbf{Z n}$ & $10.35 \mathrm{bc}$ & $10.79 \mathrm{~b}$ & $310.61 \mathrm{bc}$ & $252.72 \mathrm{~b}$ & $66.37 \mathrm{~d}$ \\
\hline DMS & 0.99 & 0.93 & 55.31 & 35.85 & 6.3 \\
\hline \multirow[t]{2}{*}{$\mathrm{CV} \%$} & 5.67 & 4.43 & 10.31 & 9.49 & 4.16 \\
\hline & \multicolumn{5}{|c|}{ Stem } \\
\hline $\mathbf{C}$ & $21.82 \mathrm{ab}$ & $2.48 \mathrm{bc}$ & $57.01 \mathrm{~b}$ & $33.63 \mathrm{~b}$ & $9.63 \mathrm{~b}$ \\
\hline$-B$ & $18.88 \mathrm{c}$ & $3.01 \mathrm{~b}$ & $56.63 \mathrm{~b}$ & $34.77 \mathrm{~b}$ & $13.75 \mathrm{~b}$ \\
\hline$-\mathrm{Cu}$ & $22.88 \mathrm{ab}$ & $0.43 \mathrm{c}$ & $54.93 \mathrm{bc}$ & $35.40 \mathrm{~b}$ & $9.42 \mathrm{~b}$ \\
\hline$-\mathrm{Fe}$ & $18.79 \mathrm{c}$ & $25.30 \mathrm{a}$ & $15.32 \mathrm{~d}$ & $76.56 \mathrm{a}$ & $55.96 \mathrm{a}$ \\
\hline$-\mathbf{M n}$ & $20.70 \mathrm{bc}$ & $1.64 \mathrm{bc}$ & $48.16 \mathrm{c}$ & $4.55 \mathrm{c}$ & $7.36 \mathrm{c}$ \\
\hline$-\mathrm{Zn}$ & $23.28 \mathrm{a}$ & $2.49 \mathrm{bc}$ & $74.46 \mathrm{a}$ & $34.87 \mathrm{~b}$ & $8.46 \mathrm{~b}$ \\
\hline DMS & 2.39 & 2.45 & 2.88 & 3.82 & 1.74 \\
\hline \multirow[t]{2}{*}{ CV\% } & 6.67 & 24.35 & 3.31 & 6.11 & 5.86 \\
\hline & \multicolumn{5}{|c|}{ Root } \\
\hline $\mathbf{C}$ & $28.22 \mathrm{~d}$ & $17.49 \mathrm{~b}$ & $724.38 b$ & $36.67 \mathrm{ab}$ & $51.12 \mathrm{c}$ \\
\hline
\end{tabular}




\begin{tabular}{clllll}
$\mathbf{- B}$ & $27.23 \mathrm{~d}$ & $15.16 \mathrm{~b}$ & $721.92 \mathrm{~b}$ & $37.72 \mathrm{a}$ & $55.87 \mathrm{~b}$ \\
$-\mathbf{C u}$ & $36.05 \mathrm{a}$ & $5.41 \mathrm{c}$ & $719.79 \mathrm{~b}$ & $39.00 \mathrm{a}$ & $53.51 \mathrm{bc}$ \\
$-\mathbf{F e}$ & $28.53 \mathrm{~cd}$ & $228.17 \mathrm{a}$ & $665.48 \mathrm{c}$ & $31.54 \mathrm{c}$ & $78.10 \mathrm{a}$ \\
$-\mathbf{M n}$ & $33.18 \mathrm{~b}$ & $12.06 \mathrm{bc}$ & $728.16 \mathrm{a}$ & $9.70 \mathrm{~d}$ & $41.59 \mathrm{~d}$ \\
$-\mathbf{Z n}$ & $32.53 \mathrm{~b}$ & $15.53 \mathrm{~b}$ & $725.76 \mathrm{~b}$ & $33.05 \mathrm{bc}$ & $36.22 \mathrm{e}$ \\
\hline M.D.S. & 2.56 & 8.8 & 19.17 & 3.54 & 3.37 \\
CV\% & 4.84 & 10.53 & 1.57 & 6.64 & 3.75
\end{tabular}

M.D.S.: minimal difference of significance; CV\%: coefficient of variation. Means followed by the same letter in the columns do not differ from each other by the test of Tukey at $5 \%$ of significance.

On the other hand, the increasing order was as follows: $\mathrm{Fe}>\mathrm{Mn}>\mathrm{B}>\mathrm{Zn}>\mathrm{Cu}$, while in root tissue, the order of micronutrients content was $\mathrm{Fe}>$ $\mathrm{Zn}>\mathrm{Mn}>\mathrm{B}>\mathrm{Cu}$. As a result, it was observed that $\mathrm{Fe}$ and $\mathrm{Cu}$ are the micronutrients in the lowest and highest amounts in all plant components of jute, respectively.

Bessa et al. (2013) found similar results for plants of Hancornia speciosa Gomez grown in a nutrient solution, with the following increasing order of micronutrients: $\mathrm{Fe}>\mathrm{Mn}>\mathrm{Cu}>\mathrm{Zn}>\mathrm{B}$, with regard to control treatment. Such concentrations were greater in this treatment than in the treatments with omission of micronutrients for this study. According to these authors, the lack of Fe among the considered nutrients is that which usually affects the content of the other nutrients as well as biomass production in a more expressive way.

Overall, it was observed that the omission of $\mathrm{Fe}$ promoted an increase in the content of $\mathrm{Mn}, \mathrm{Zn}$, and $\mathrm{Cu}$, in leaves, stem, and root of jute plants in comparison to $\mathrm{C}$ treatment. This is probably due to the competitive inhibition, which occurs among these micronutrients, especially in the absorption process (Marschner, 2012). The Table 3 shows the correlations among micronutrients content in each treatment. Only significant correlations are shown in such table, in agreement with Pearson's test at 5\% of significance.

Table 3. Pearson's Correlation Analysis between micronutrients content in different plant tissues for each treatment.

\begin{tabular}{llll}
\hline & T1-Complete Solution & & \\
\hline Correlation & & Level & Significance \\
\hline B Stem x Fe Leaf & -0.9736 & $* *$ \\
Fe Stem x Mn Leaf & 0.9526 & $*$ \\
Mn Stem x Fe Root & -0.9404 & $*$ \\
B Root x Mn Root & -0.9444 & $*$ \\
B Root x Zn Root & 0.9287 & $*$ \\
\hline Correlation & & \\
\hline B Stem x Zn Root & T2-B Omission & Level & Significance \\
Cu Stem x Zn Stem & -0.9818 & $* *$ \\
Fe Stem x Fe Leaf & 0.9573 & $*$ \\
B Leaf x Cu Root & & -0.9472 & $*$ \\
Cu Leaf x Mn Leaf & -0.9753 & $* *$ \\
B Root x Mn Root & & 0.9175 & $*$ \\
\hline & & -0.9813 & $* *$ \\
\hline Correlation & & & \\
\hline B Stem x Fe Root & & Level & Significance \\
Cu Stem x Cu Root & & -0.9820 & $* *$ \\
Fe Stem x Fe Leaf & & 0.9242 & $*$ \\
Fe Stem x Fe Root & & 0.8901 & $*$
\end{tabular}




\begin{tabular}{|c|c|c|}
\hline Mn Stem x Cu Leaf & -0.9846 & $* *$ \\
\hline Mn Stem x B Root & -0.9867 & $* *$ \\
\hline Zn Stem x Zn Root & -0.9258 & $*$ \\
\hline B Leaf x Zn Leaf & 0.9728 & $* *$ \\
\hline Cu Leaf x B Root & 0.9922 & $* *$ \\
\hline Fe Leaf x Mn Leaf & -0.9879 & $* *$ \\
\hline \multicolumn{3}{|c|}{ T4-Fe Omission } \\
\hline Correlation & Level & Significance \\
\hline B Stem x B Leaf & 0.8952 & $*$ \\
\hline Mn Stem x Cu Root & 0.9914 & $* *$ \\
\hline Zn Stem x Zn Root & -0.9925 & $* *$ \\
\hline Fe Leaf x Mn Leaf & -0.9363 & $*$ \\
\hline Zn Leaf x Cu Root & -0.9035 & $*$ \\
\hline \multicolumn{3}{|c|}{ T5-Mn Omission } \\
\hline Correlation & Level & Significance \\
\hline Cu Stem x Zn Stem & -0.9805 & $* *$ \\
\hline Fe Stem x Mn Stem & 0.8897 & $*$ \\
\hline Fe Stem x Fe Root & -0.9936 & $* *$ \\
\hline Mn Stem x Mn Root & 0.9127 & $*$ \\
\hline B Leaf x Fe Leaf & -0.8937 & $*$ \\
\hline B Root x Zn Root & 0.9150 & $*$ \\
\hline \multicolumn{3}{|c|}{ T6-Zn Omission } \\
\hline Correlation & Level & Significance \\
\hline Mn Stem x Zn Stem & -0.9052 & $*$ \\
\hline Mn Stem x Zn Leaf & -0.9719 & $* *$ \\
\hline Mn Stem x Cu Root & 0.9611 & $* *$ \\
\hline B Leaf x Zn Leaf & 0.9256 & $*$ \\
\hline $\mathrm{Cu}$ Leaf $x$ Fe Root & -0.8984 & $*$ \\
\hline Zn Leaf x Cu Root & -0.8914 & $*$ \\
\hline
\end{tabular}

Obs.: Only the significant correlations (at $5 \%$ and at $1 \%$ of significance) are shown in this Table.

For Complete Solution Treatment, we found that $\mathrm{B}$ content was reducing with the increasing of $\mathrm{Mn}$ in jute root, and had a positive correlation with $\mathrm{Zn}$ content in this plant tissue. Mn may inhibit the radicular absorption of $\mathrm{B}$, as well as $\mathrm{B}$ is able to increase zinc absorption process (MALAVOLTA, 2006).

For the significant correlations found in $-\mathrm{B}$, we realized a negative correlation among Fe content in stem and leaves. This result may indicate a transport of Fe from stem to leaf, since B content in leaves was greatly decreased. According to Malavolta (2006), B and Fe use to inhibit each other, which can explain such result.

In $\mathrm{Cu}$ omission treatments, the main correlations were among $\mathrm{Fe}, \mathrm{Mn}$ and $\mathrm{B}$ contents. These elements use to inhibit one another (Novais et al., 2007), which can be intensified with the absence of $\mathrm{Cu}$ in nutrient solution. Another result observed was the negative correlation between $\mathrm{Cu}$ in stem and root system. This result is probably due to the translocation of this nutrient from root system to stem tissues, which is provoked by its deficiency (MALAVOLTA et al., 1997).

In $-\mathrm{Fe}$ treatment, it was found that boron concentrations proportionally increased in stem tissue and leaves. Moreover, an increase of $\mathrm{Mn}$ content was observed with the decrease of $\mathrm{Fe}$ in leaves, probably because of the competitive inhibition, which occurs among them. Similar results were found in correlations from $-\mathrm{Mn}$ treatment. Lange et al. (2005) performed a research in order to testify the effect of micronutrients omission in growth of castor bean. The authors observed that the omission of $\mathrm{Fe}$ led to a greater amount of $\mathrm{Mn}$ in plant tissues, probably because of the increase of absorption process of Mn. 
The $\mathrm{Zn}$ content had a negative correlation with $\mathrm{Mn}$ content in stem and leaves for treatment with omission of $\mathrm{Zn}$ in nutrient solution. Malavolta et al. (1997) highlight the great influence among these nutrients due to the elevated competitive inhibition. Thus, the small amount of $\mathrm{Zn}$ due to the lack of such micronutrient in nutrient solution could led to an increase of Mn content.

\section{CONCLUSIONS}

Excluding the $-\mathrm{Cu}$ treatment, all treatments with omissions provided morphological changes in leaves established as visual symptoms of deficiency.

In general, -Fe and -B were the nutrients which most influenced the growth and development of the jute. In jute plants, the omission of $\mathrm{B}, \mathrm{Mn}$, and $\mathrm{Fe}$ reduces more expressively root growth, while the omission of $\mathrm{Zn}$ and $\mathrm{Cu}$ affected shoot growth more.

By considering the treatment without omission of micronutrients, it is suggested that the suitable contents of micronutrients $\mathrm{B}, \mathrm{Cu}, \mathrm{Fe}, \mathrm{Mn}$, and $\mathrm{Zn}$, in leaves tissue of jute plants, are 11.37; $8.99 ; 346.14 ; 248.88$ and $77.28 \mathrm{mg} \mathrm{kg}{ }^{-1}$, respectively.

\section{ACKNOWLEDGEMENTS}

The authors thank Universidade Federal Rural da Amazônia and Embrapa Amazônnia Oriental and further collaborators for the support given to carry out such study.

RESUMO: O conhecimento acerca de micronutrientes em plantas de juta (Corchorus capsularis L.) pode ser uma importante ferramenta para subsidiar tomadas de decisão quanto ao manejo de tal espécie. O objetivo do presente estudo foi descrever os sintomas de deficiência de micronutrientes em plantas de juta e analisar o teor de micronutrientes contidos em folhas, caules e raízes. $\mathrm{O}$ experimento foi conduzido em casa de vegetação, com seis tratamentos e quatro repetições para cada tratamento em delineamento em blocos ao acaso. Os tratamentos foram: solução completa (C) e solução com a omissão dos seguintes nutrientes: B, Cu, Fe, Mn e Zn. Com exceção da deficiência de $\mathrm{Cu}$, as alterações morfológicas foram fáceis de caracterizar para todos os nutrientes analisados, com Fe e Zn sendo o primeiro e o último a causar sintomas em plantas, respectivamente. Em geral, os nutrientes que foram os mais limitantes para o crescimento e matéria seca de juta foram Fe e B. A omissão de B, Mn e Fe limitou o crescimento radicular, enquanto que a deficiência de $\mathrm{Zn}$ e Culimitou o crescimento da parte aérea. O teor de nutrientes seguiu a seguinte ordem decrescente: Fe $>\mathrm{Mn}>\mathrm{Zn}>\mathrm{B}>$ $\mathrm{Cu}$ nas folhas, $\mathrm{Fe}>\mathrm{Mn}>\mathrm{B}>\mathrm{Zn}>\mathrm{Cu}$ no caule e $\mathrm{Fe}>\mathrm{Zn}>\mathrm{Mn}>\mathrm{B}>\mathrm{Cu}$ nas raízes. Pra mudas de juta, a deficiência de $\mathrm{Fe}$ e $\mathrm{B}$ são as mais limitantes e os teores nutricionais adequados para estas mudas são 11,$37 ; 8.99 ; 346.14 ; 248.88$; and 77.28 $\mathrm{mg} \cdot \mathrm{kg}^{-1}$, respectivamente, para $\mathrm{B}, \mathrm{Cu}, \mathrm{Fe}, \mathrm{Mn}$ and $\mathrm{Zn}$ nas folhas.

PALAVRAS-CHAVE: Corchorus capsularis L. Nutrição mineral. Demanda por micronutrientes. Solução nutritiva. Desenvolvimento vegetal.

\section{REFERENCES}

ALMEIDA, E. I. B.; NOBREGA, G. N.; CORREA, M. C. M. Crescimento e marcha de absorção de micronutrientes para a cultivar de melancia Crimson Sweet. Revista Agro@mbiente, Boa Vista, v. 8, n. 1, p. 74-80, 2014.

BESSA, L. A.; SILVA, F. G.; MOREIRA, M. A.; TEODORO, J. P. R.; SOARES, F. A. L. Characterization of nutrient deficiency in Hancornia speciosa Gomes seedlings by omitting micronutrients from the nutrient solution. Revista Brasileira de Fruticultura, v. 35, n. 2, p. 616 - 624, 2013. https://doi.org/10.1590/S010029452013000200034

BOLLE-JONES, E. W. Nutrition of (Hevea brasiliensis). II Effects of nutrient deficiencies on growth, chlorophyll, rubber and contents of tjirandji seedlings. Journal of Rubber Research institute of Malaya, v. 14, n. 2, p. 209-219, 1954.

BRADY, N. C.; WEIL, R. R. Elementos da Natureza e Propriedades dos Solos. Porto Alegre: Editora Bookman, 2013. 685 p. 
CHOUDHARY, S. B.; SHARMA, H. K.; KARMAKAR, P. G.; KUMAR, A. A.; SAHA, A. R.; HAZRA, P.; MAHAPATRA, B. S. Nutritional profile of cultivated and wild jute (Corchorus) species. Australian Journal of Crop Science, v. 7, n. 13, p. 1973-1982, 2013.

FAÇANHA, A. R.; CANELLAS, L. P.; DOBBS, L. B. Nutrição mineral. In: ed. Fisiologia Vegetal. Rio de Janeiro: Guanabara Koogan, 2008. p. 33-49. KERBAUY, G. B. (Ed.) 2

FERNANDES, A. R.; BRAZ, A. M. S.; MAIA, P. R.; VIÉGAS, I. J. M. Phosphorus fertilization and base saturation in the formation of Swietenia macrophyla seedlings. Revista de Ciências Agrárias, Belém, v. 56, n. 3, p. 261-267, 2013. https://doi.org/10.4322/rca.2013.041

FERREIRA, M. M. M. Sintomas de deficiência de macro e micronutrientes de plantas de milho híbrido BRS 1010. Revista Agro@mbiente, Boa Vista, v. 6, n. 1, p. 74-83, 2012.

HIROCE, R.; BENATTI JÚNJOR, R.; ABRAHÃO, J. T. M. Marcha de absorção de nutrientes pela juta (Corchorus olitorius L.) cultivada em casa de vegetação. Revista de Agricultura, Piracicaba, v. 62, n. 3, p. 281-288, 1987.

LANGE, A.; MARTINES, A. M.; SILVA, M. A. C.; SORREANO, M. C. M.; CABRAL, C. P.; MALAVOLTA, E. Efeito de deficiência de micronutrientes no estado nutricional da mamoneira cultivar Iris. Pesquisa Agropecuária Brasileira, Brasília, v. 40, n. 1, p. 61-67, 2005. https://doi.org/10.1590/S0100204X2005000100009

MAFFEIS, A. R.; SILVEIRA, R. L. V. A.; BRITO, J. O. Reflexos das deficiências de macronutrientes e boro no crescimento de plantas, produção e qualidade de óleo essencial em Eucalyptus citriodora. Scientia Forestalis, Piracicaba, v. 57, p. 87-98, 2000.

MALAVOlTA, E. Manual de Nutrição Mineral de Plantas. São Paulo: Ceres, 2006, 638 p.

MALAVOLTA, EURÍPEDES; VITTI, GODOFREDO CESAR; OLIVEIRA, ALBERTO. Avaliação do estado nutricional das plantas: princípios e aplicações. 2. ed. Piracicaba: Potafos, 1997. 319 p.

MARSCHNER, H. Mineral nutrition of higher plants. 3. ed. New York: Academic Press, 2012. 625 p.

MATOS, G. S. B.; FERNANDES, A. R.; CARVALHO, J. G. Symptoms of deficiency and growth of peach palm seedlings due to omission of micronutrients. Revista de Ciências Agrárias, Belém, v. 56, n. 2, p. 166172, 2013. https://doi.org/10.4322/rca.2013.025

MIRANDA, R. S.; SUDÉRIO, F. B.; SOUZA, A. F.; GOMES FILHO, E. Deficiência nutricional em plântulas de feijão-de-corda decorrente da omissão de macro e micronutrientes. Revista Ciência Agronômica, Fortaleza, v. 41, n. 3, p. 326-333, 2010. https://doi.org/10.1590/S1806-66902010000300002

MORETTI, B. S.; FURTINI NETO, A. E.; BENATTI, B. P.; PÁDUA, E. J.; SANTOS, L. L.; LACERDA, J. J. J.; DECCETTI, S. F. C. Characterization of Micronutrient Deficiency in Australian Red Cedar (Toona ciliata M. Roem var. australis). International Journal of Forestry Research, v. 587094, p. 1-9, 2012. https://doi.org/10.1155/2012/587094

NOVAIS, R.F.; NEVES, J.C.L.; BARROS, N.F. Ensaio em ambiente controlado. In: OLIVEIRA, A.J., GARRIDO, W.E., ARAÚJO, J.D., AND LOURENÇO, S. (Ed.) Métodos de pesquisa em fertilidade do solo. Brasília: Embrapa-Sea, 1991. p.189-255.

PINHO, L. G. R.; MONNERAT, P. H.; PIRES, A. A.; SANTOS, A. L. A. Absorção e redistribuição de boro em coqueiro-anão-verde. Pesquisa Agropecuária Brasileira, Brasília, v. 43, n. 12, p. 1769-1775, 2008. https://doi.org/10.1590/S0100-204X2008001200018 
SCHMIDT, S. B.; JENSEN, P. E.; HUSTED, S. Manganese Deficiency in Plants: The Impact on Photosystem II. Trends in Plant Science, v. 21, n. 7, p. 622-632, 2016. https://doi.org/10.1016/j.tplants.2016.03.001

Crescimento e teores de boro em plantas de eucalipto (Eucalyptus citriodora) cultivadas em dois latossolos sob influência de doses de boro e disponibilidade de água. Revista Árvore, v. 33, n. 1, p. 57-65, 2009.

https://doi.org/10.1590/S0100-67622009000100007

SAKYA, A.T.; DELL, B.; HUANG, L. Boron requeriments for Eucalyptus globulus seedlings. Plant and Soil, v. 246, n. 1, p. 87-95, 2002. https://doi.org/10.1023/A:1021589029492

SAS Institute Inc. Statistical analysis system user's guide. Version 9.1. Statistical Analysis System Institute, 2006. 34 p.

SILVA, J.F.; MOTA, M.G.C. Competição entre cultivares de juta local vs linhagem introduzida da Índia. Embrapa-UEPAE de Belém, Belém, v. 3, p. 1-6, 1991. https://doi.org/10.1590/S0044-59672007000200004

SILVA, A. R. M.; TUCCI, C. A. F.; LIMA, H. N.; FIGUEIREDO, A. F. Doses crescentes de corretivo na formação de mudas de mogno (Swietenia macrophylla King). Acta Amazonica, Manaus, v. 37, n. 2, p. 195200, 2007.

SILVEIRA, R. L. V. A.; TAKAHASHI, E. N.; SGARBI, F.; CAMARGO, M. A. F.; MOREIRA, A. F. Crescimento e estado nutricional de brotações de Eucalyptus citriodora sob doses de boro em solução nutritiva. Scientia Forestalis, Piracicaba, v. 57, p. 53-67, 2000.

TAIZ, L.; ZEIGER, E. Plant Physiology. 5. ed. Sunderland: Sinauer Associates Inc., 2010. 826 p.

VIÉGAS, I. J. M.; HAAG, H. P.; SILVA, J. F.; MONTEIRO, F. A. Carência de macronutrientes e de boro em plantas de juta (Corchorus capsularis), variedade roxa. EMBRAPA- CPATU Boletim de Pesquisa, Belém, n. 138, p. 1-10, 1992. https://doi.org/10.1590/S0100-29452004000200032

VIÉGAS, I. J. M.; THOMAZ, M. A. A.; SILVA, J. F.; CONCEIÇÃO, H. E. O.; NAIFF, A. P. M. Efeito da omissão de macronutrientes e boro no crescimento, nos sintomas de deficiências nutricionais e na composição mineral de plantas de camucamuzeiro. Revista Brasileira de Fruticultura, Jaboticabal, v. 26, n. 2, p. 315-319, 2004. https://doi.org/10.1016/j.still.2005.11.009

WEI, X.; HAO, M.; SHAO, M.; GALE, W. J. Changes in soil properties and the availability of soil micronutrients after 18 years of cropping and fertilization. Soil \& Tillage Research, v. 91, p. 120-130, 2006.

WATRIN, O. S.; HOMMA, A. K. O. Evolução do uso da terra do Engenho Murutucu: história, geografia e ecologia. Belém: Embrapa Amazônia Oriental, 2011. 34 p. 